\title{
The relationship between Monitoring and Evaluation (M\&E) practices and public projects performance in $R$ wanda with reference to Science and Technology Skills Development (STSD) project
}

\author{
Odile Muhayimana $^{1}$ and James Kant Kamuhanda ${ }^{2}$ \\ ${ }^{1,2}$ School of Social sciences, Mount Kenya University, \\ Kigali, Rwanda
}

\begin{abstract}
Many public projects face issues of poor performance that are mostly related to project timeliness, inefficiency and ineffective cost that can be traced by monitoring and evaluation practices to improve performance of projects in Rwanda. In this sense, the researcher conducted a study to assess the relationship between monitoring and evaluation practices and performance of public projects in Rwanda with emphasis on Science and Technology Skills Development (STSD) project in Ministry of Education (MINEDUC). In the case of the study, the researcher has invested in explanatory research design to enable data collection instruments to capture each qualitative and quantitative statistic that gave an explanation and replicate the existence of situation at the field in the preferred way. The goal population was 146 obtained through census sampling technique. For a suitable time of facts collection, the researcher used questionnaire research tools that was given to both project beneficiaries and monitors and interview guide that collected information from a small number of the respondents that was chosen from managerial staffs and donors of the project in responding to questions that provided detailed information regarding Monitoring and Evaluation and performance of Science and Technology Skills Development project in Rwanda. The collected data was edited, coded and analyzed in new version of IBM 22.0 and the findings were presented in tables of frequency, correlation and regression. The results have shown that there is relationship between Linking M\&E plan to Action\& Strategic plans and Efficiency $(r=.476$ and $\mathrm{p}=.000)$, between Linking M\&E plan to Action\& Strategic plans and Project time line ( $r=.987$ and $\mathrm{p}=.000)$, between Linking M\&E plan to Action\& Strategic plans and Cost effectiveness $(r=.471$ and $\mathrm{p}=.000)$ between
\end{abstract}

Employing participatory approach and Efficiency $(\mathrm{r}=.496$ and $\mathrm{p}=.000)$ between Employing participatory approach and Project time line $(\mathrm{r}=.602$ and $\mathrm{p}=.000)$ between Employing participatory approach and Cost effectiveness $(\mathrm{r}=.469$ and $\mathrm{p}=.000)$ between Disseminating $\mathrm{M} \& \mathrm{E}$ results to stakeholders and Efficiency $(r=.455$ and $\mathrm{p}=.000$ ) between Disseminating $\mathrm{M} \& \mathrm{E}$ results to stakeholders and Project time line $(r=.945$ and $\mathrm{p}=.000)$ between Disseminating M\&E results to stakeholders and Cost effectiveness $(r=.472$ and $\mathrm{p}=.000$ ) because all calculated $\mathrm{p}$ - values are less than 0.01 level of significance. This implies that there is a positive relationship between M\&E practices and performance of public projects. The results have also shown that the $\mathrm{R}$ coefficient .988 reveals that M\&E practices have a positive relationship with project timeline. The coefficient of determination $.977 \mathrm{R}$ square also indicates that M\&E practices explains $97.7 \%$ the progress variability in project timeline. Thus, it implies that predictors of M\&E practices such as Linking M\&E plan to Action\& Strategic plans, Employing participatory approach and Disseminating $\mathrm{M} \& \mathrm{E}$ results to stakeholders affect the progress of project timeline by $97.7 \%$ in STSD project hence, the researcher recommends project stakeholders to link M\&E plan to action and strategic plans, employ participatory approach, and disseminate $\mathrm{M} \& \mathrm{E}$ results and use of data to improve performance of STSD project in MINEDUC, Rwanda.

\section{Introduction}

Globally, practices of M\&E are the best tools to measure the success and performance of both private and public projects through involvement of key stakeholders with the process (Buttrick, 2007). Consequently, most of the organizations to make 
any success, they desire to make it wonderful that their initiatives succeed first because of practices used in control and contrast. There should be a larger effort of Linking M\&E plan to Action\& Strategic plans to embellish the splendid administration of task activities, accountability and transparency in the work of tasks than to the effectiveness of the allocation of equipment, the timely completion of the task and the achievement of greater challenge results. (Porter \&amp; Goldman, 2013).

Monitoring and evaluation is made up of best practices such as the ability to link the M\&E plan to the Strategic plan and work plan, employing participatory approach, dissemination of M\&E results to stakeholders and use of $M \& E$ datafor Project Improvement(Kusek and Rist, 2010). It is very crucial to note the benefits of monitoring and those of evaluation of public projects given the reason that the resources channeled by the country and other donors have to be well managed to ensure performance of projects.

The empirical literature shows that there is no empirical study conducted in Rwanda about the effect of monitoring and evaluation on public initiatives in Rwanda. Although, monitoring and evaluation were adopted throughout the government institutions and departments to evaluate the progress of the use of budget and track failures of government projects (OAG, 2015). Therefore, performance in public projects may be indicated by achievement of the project
ISSN 2455-6378

deliverables, timely completion of industrial enterprise within the estimated budget and quality of work. It is in this essence that it was found necessary to investigate the effect of $M \& E$ practices on the performance of STSD project in MINEDUC, Rwanda.

Moreover, most of public projects delay to be completed and/or completely fail despite the huge amount of money invested by Governments and donors. This is mostly due to ineffective monitoring and evaluation. Hence, the best practices of monitoring and evaluation require projects to closely monitor and control the accountability and transparency of management team for use of resources and achievement of the mission and organizational domain of initiatives that advantage future initiatives.

\section{Literature Review}

\subsection{Linking the M\&E Plan to the Strategic Plan and Work plan}

When managing project for performance, strategic plan, annual planning and $\mathrm{M} \& \mathrm{E}$ plan become linked processes. Aligning M\&E plan with existing systems minimizes duplication or additional features that overburden project control. While such a linkage may seem to be an obvious necessity, the M\&E plan is exceptional in that all work plan activities are drawn from the specific strategic results and are tracked by corresponding indicators (USAID, 2019).

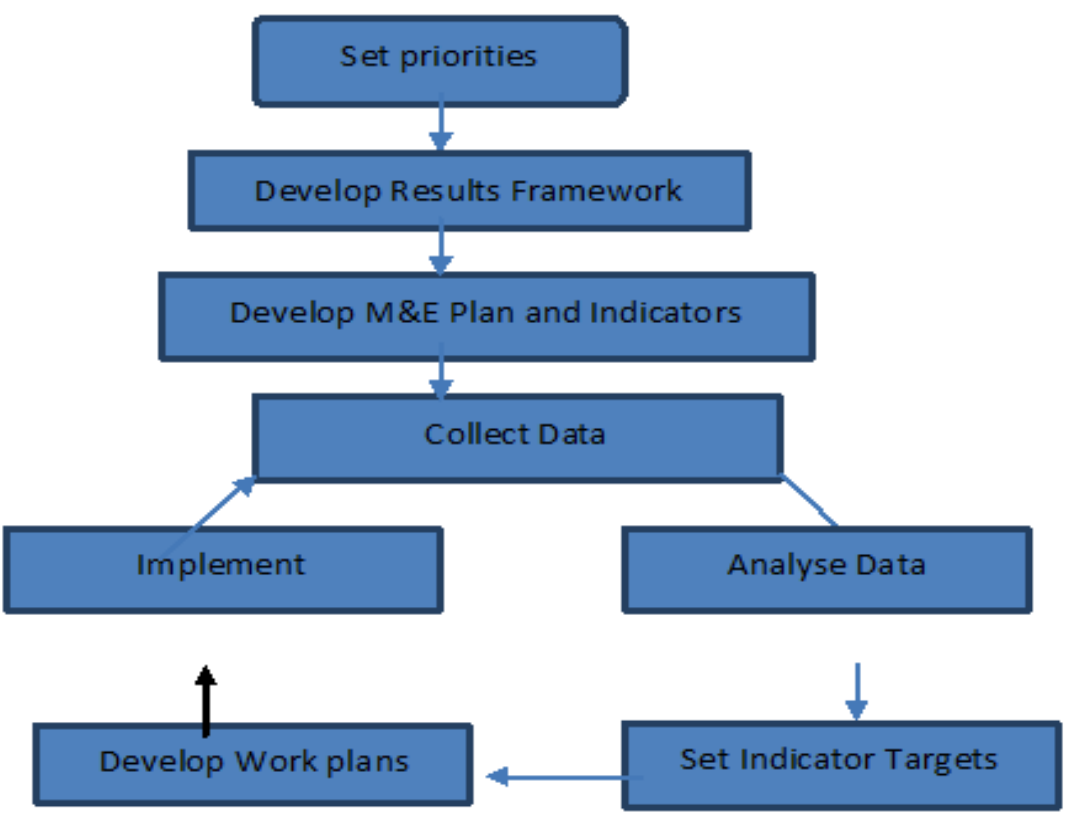

Figure 2. 1: M\&E Cycle 
The collection of data for the M\&E plan is but one step in a standard program planning process, which contains the elements detailed in the M\&E Cycle mentioned in the figure above. Thus, the annual collection of data forms a continual feedback loop which drives the revision of targets and the development of program work plans.

\subsection{Employ a Participatory Approach}

Participatory approach in Monitoring and Evaluation known as Participatory Monitoring and Evaluation (PM\&E) is a process through which stakeholders at various levels engage in monitoring or evaluating a particular project, program or policy, share control over the content, the process and the results of the M\&E activity and engage in taking or identifying corrective actions (World Bank, 2010a). PM\&E focuses on the active engagement of primary stakeholders.

PM\&E is ranked as one of the best approaches to ensure the project is implemented within the action plan and leads to the expected outcomes.

In a convention way, M\&E has involved outside experts coming in to measure performance against pre-set indicators, using standardized procedures and tools. PM\&E differs from more conventional approaches in that it seeks to engage key project players more actively in reflecting and assessing the progress of their project and in particular the achievement of results (World Bank 2010a). PM\&E is based on the following core principles (World Bank, 2010b):

Local people are active participants-not just sources of information; Stakeholders evaluate outsiders facilitate; Focus on building stakeholder capacity for analysis problem solving; Process builds commitment to implementing any recommended corrective actions.

Kimweli (2013) has demonstrated four steps in development and implementation of a PM\&E process including the first step which is planning the PM\&E Process and determining objectives and indicators. At the initial stage, the first activity is to identify the group of stakeholders to be involved in the planning of the PM\&E process, and stakeholders must define the objectives of the PM\&E, including what will be monitored, how and by whom.

The second of gathering Data refers data collection can include both qualitative and quantitative methods and tools. Various methods can be used in this type of data collection. Those include community surveys, interviews and observations. The third step of analyzing data; while data analysis is often thought of as a rather mechanical and expert driven task, PM\&E should be an opportunity to actively involve various categories of program/project stakeholders in the critical
ISSN 2455-6378

analysis of successes and constraints and the formulation of conclusions and lessons learned.

The fourth step is about sharing the information and defining actions to be taken; in this step, the PM\&E process doesn't necessary use the same stakeholders involved in steps 1 to 3 . This time the results of M\&E activities are shared with other stakeholders, and there is discussion of appropriate actions to be taken based on the findings.

\subsection{Dissemination of M\&E Results to Stakeholders}

Dissemination of information from M\&E activities at different levels and through different means should take place and the plan to be built into the M\&E system. When preliminary results of the M\&E activities become available, they are first shared with the M\&E task force for discussion and inputs. The feedback from the M\&E task force is incorporated in the report to make final report that was disseminated to a broad group of stakeholders. It is noted that broad dissemination and discussion of results at all levels enables an exchange of information, creative thinking and innovative solutions to identified issues.

\subsection{Facilitate the Use of Data for Project Improvement}

The M\&E plan facilitates the use of living data for rapid project improvement. Results collected under M\&E system that are incorporated into feedback reports are shared with local level managers to enable them to (USAID,2019):

Identify and understand M\&E results; Understand the standards set for particular indicators; Understand how the indicators were measured; Compare the actual data with the project targets; Propose correction measures; Follow up on the implementation of the correction measures and Report on change brought by the M\&E data vis-àvis project targets.

\subsection{Performance of Public Projects}

Project performance is relatively considered as project success and it was simplified from its setting of criteria or standards for measuring project deliverables. Initially and over a significant period of time, project success was measured from a constricted universally accepted criteria of time, scope and cost (Muller \& Turner, 2007). Over the years, this has now been expanded to include other criteria such as meeting strategic objectives and financial objectives of the enterprises and generally enveloped in stakeholder satisfaction.

Pinto and Slevin (2008) searched for a broader framework for project success. Postulating that project success was a result of both project and proponents' factors. Project factors being time, 
cost, and performance all of which the project manager has substantial control over. Proponents factors being utility, gratification, and efficacy of the project outcome; regrettably, these factors cannot be assessed before the completion of the project; one can only guarantee them during project execution, up to a certain point, by way of comprehending client needs and transforming them into specifications of the project deliverables.

Project performance can be evaluated using measurement like quality of the project, timeliness of the project and cost required to finish project as the indication of performance without forget satisfaction of project stakeholders (Cheung, Seun, $\&$ Cheung, 2014). The same, quality, value and time are three predominant dimensions of overall performance appraisal (Enchass, Mohamed, \&Abushaban, 2009). The fee of finishing tasks and the pleasure of the pattern is at the exit of the mission (Pintom\&Mantel, 2009). Project performance consists of mission efficiency (completion of the mission inside the planned timeframe and cost), benefits of the product closure pattern, project performance; future planning of market chances (Shenharet al., 2011). For this study, performance of fruit export project can be evaluated using indicators such as project profitability, stakeholder satisfaction and welfare improvement because since the project is run in community with participation this project involves joint consultation and collective decision making to enhance its empowerment.

The dimensions of project performance are dependent on time and technological uncertainty as stated project management studies (Bryde, 2008). Project performance has been measured cost and time as specifications like quality to finish the project (Muller, \&Tumer, 2007). In addition, meeting expectations of customer is added to other dimensions of project performance (Morrison, Brown \&Smith 2008). The level of project team satisfaction by working together as the community participates also in project performance (Doolen et al., 2003). Project performance is also divided into constructs such as venture effectiveness together with cost, time, and assembly specifications; and the effectiveness of the project in enhancing stakeholder well-being and self-help activities (Dvir et al., 2006).

In the case of this study, the performance of the STSD project is measured in sentences of timeliness and cost effectiveness. Monitoring practices in public projects like in the STSD project are used for the interest of activities, for timely completion of project on a planned cost and with quality.
ISSN 2455-6378

\section{Research Methodology}

Investigator adopted explanatory research design with a mixed approach of qualitative and quantitative information that was linked because they built broader understandings of the phenomenon at the field and facilitate the use of different perspectives that facilitate to capture the minimal statistical data as planned. This permitted the researcher to collect quantitative and qualitative data that delivers detailed explanation about the situation of M\&E practices and its effect on STSD project performance in MINEDUC, Rwanda.

This research was carried out in Kigali City, and it made emphasis practices of $\mathrm{M} \& \mathrm{E}$ that affect performanceof STSD project in MINEDUC, Rwanda. It involved a target population of 7 project staff, 5 monitors, 124 beneficiaries and 10 donors who were chosen purposively to increase the number to 146 people to be involved in this study. Investigator used census method because this study involved a reasonable number of people. The census method was used to minimize sampling errors due to the fact that this methodfacilitated the work of the researcher in collecting, analyzing, and decrypting records in a relevant manner that gives equal opportunity to all the elements of population targeted to participate.Hence, 146 project participants became research participants as primary respondents of the study.

Investigator employed a variety of tools to help meet data cravings while collecting statistics from the subject, the use of the questionnaire and different key records sources, such as primary and secondary records.

During actual time of series of researcher information, acquire files and the facts, be gathered from field using primary data and get analyzed by the use of new version of SPSS IBM 22.0 and the findings, be presented in tables of frequency, Pearson correlation analysis, be considered to come with relationship between the predicators of monitoring and evaluation which are Linking M\&E plan to Action\& Strategic plans, Employing participatory approach, Dissemination of $M \& E$ results to stakeholders and facilitate the use of data for project improvement; with each measure of project performance that are represented by project timeliness, efficiency and cost effectiveness.

As mentioned above data was presented in descriptive table indicating frequencies and percentages, correlation tables that indicates Pearson correlation and level of significance, the researcher, also use regression analysis to present data, through a regression model with a linear equation of $Y=\beta_{0}+\beta_{1} X_{1}+\beta_{2} X_{2}+\beta_{3} X_{3}+\beta_{4} X_{4}+\beta$. Where: $\beta_{0}=$ Constant, $X_{1}=$ represents linking $M \& E$ plan to action\& strategic plans, $X_{2}=$ represents 
employing participatory approach, $\mathrm{X}_{3}=$ represents disseminating the $\mathrm{M} \& \mathrm{E}$ results to stakeholders, $\mathrm{X}_{4}=$ facilitating the use of data for project improvement and $\beta_{1}, \beta_{2}, \beta_{3}$ and $\beta_{4}$ that represent regression coefficients.

\section{Results and Discussions}

\subsection{Bio-Graphic Data of Respondents}

This part deals with gender and educational level of respondents which help to analyze, present and interpret the research findings.

Table 4. 1: Gender respondents

\begin{tabular}{lcc}
\hline & Frequency & Percent \\
\hline Male & 105 & 71.9 \\
Female & 41 & 28.1 \\
Total & 146 & 100.0 \\
\hline
\end{tabular}

Source: Primary Data, 2020

The results in Table 4.1 indicated that 105 (71.9\%) of respondents who participated in this study are males, while $41(28.1 \%)$ of respondents who participated in this study are females. Thus, implies that Science and Technology Skills Development project is gender sensitive in nature.

Table 4. 2: Education level of respondents

\begin{tabular}{lcc}
\hline & Frequency & Percent \\
\hline Primary education & 6 & 4.1 \\
Secondary & 14 & 9.6 \\
education & & \\
University & 106 & 72.6 \\
education & & \\
Master level & 20 & 13.7 \\
Total & 146 & 100.0 \\
\hline
\end{tabular}

Source: Primary Data, 2020

The results in Table 4.2 indicated that 106 (72.6\%) of respondents have university level of education,
ISSN 2455-6378

$20(13.7 \%)$ of respondents have masters level of education, $14(9.6 \%)$ of respondents have secondary level of education, and only $6(4.1 \%)$ of respondents who participated in this study are primary education, while $6(4.1 \%)$ of respondents have only completed primary level of education. Thus, this implies that a big number of respondents have university level among in Science and Technology Skills Development Project in MINEDUC.

4.2 Relationship between M\&E Practices and Performance of Public Projects in Rwanda

The relationship between M\&E practices and performance of public projects in Rwanda is analyzed basing the variables of the study including M\&E practices and performance of public projects by correlating the predictors of M\&E Practices themselves, correlating indicators of performance in public projects themselves and join both in one correlational matrix. The results have also focused on regression analysis with predictors of $\mathrm{M} \& \mathrm{E}$ practices to each indicators of public project performance in STSD project in MINEDUC, Rwanda.

The findings in Table 4.3proved that there is a relationship between Linking M\&E plan to Action\& Strategic plans and Employing participatory approach $(\mathrm{r}=.610$ and $\mathrm{p}=.000)$, between Linking M\&E plan to Action and Strategic plans and Disseminating $\mathrm{M} \& \mathrm{E}$ results to stakeholders $(r=.970$ and $\mathrm{p}=.000)$, between Employing participatory approach and Disseminating M\&E results to stakeholders $(r=.558$ and $\mathrm{p}=.000)$, because all calculated $\mathrm{p}$ - values are less than 0.01 level of significance. Thus, implies that there is a positive relationship between predictors of M\&E practices in Science and Technology Skills Development Project of MINEDUC in Rwanda

Table 4.3: Correlation analysis between predictors of $M \& E$ practices in STSD project

\begin{tabular}{|c|c|c|c|c|}
\hline & & $\begin{array}{l}\text { Linking M\&E plan to } \\
\text { Action\&Strategic plans }\end{array}$ & $\begin{array}{c}\text { Employing participatory } \\
\text { approach }\end{array}$ & $\begin{array}{l}\text { Disseminating } \\
\text { M\&E results to } \\
\text { stakeholders }\end{array}$ \\
\hline \multirow{2}{*}{$\begin{array}{l}\text { Linking M\&E plan } \\
\text { to Action\& }\end{array}$} & P Correlation & $\overline{1}$ & $.610^{* *}$ & $.970^{* *}$ \\
\hline & Sig. (2-tailed) & & .000 & .000 \\
\hline Strategic plans & $\mathrm{N}$ & 146 & 146 & 146 \\
\hline \multirow{3}{*}{$\begin{array}{l}\text { Employing } \\
\text { participatory } \\
\text { approach }\end{array}$} & P Correlation & $.610^{* *}$ & 1 & $.558^{* *}$ \\
\hline & Sig. (2-tailed) & .000 & & .000 \\
\hline & $\mathrm{N}$ & 146 & 146 & 146 \\
\hline \multirow{3}{*}{$\begin{array}{l}\text { Disseminating } \\
\text { M\&E results to } \\
\text { stakeholders }\end{array}$} & P Correlation & $.970^{* * *}$ & $.558^{* *}$ & 1 \\
\hline & Sig. (2-tailed) & .000 & .000 & \\
\hline & $\mathrm{N}$ & 146 & 146 & 146 \\
\hline
\end{tabular}

**. Correlation is significant at the 0.01 level (2-tailed).

Source: Primary Data,2020 
Table 4.4: Correlation Analysis between measures of STSD Project Performance

\begin{tabular}{ccccc}
\hline & & Efficiency & Project time line & Cost effectiveness \\
\hline \multirow{2}{*}{ Efficiency } & Pearson Correlation & 1 & $.482^{* * *}$ & $.978^{* *}$ \\
& Sig. (2-tailed) & & .000 & .000 \\
Project time line & $\mathrm{N}$ & 146 & 146 & 146 \\
& Pearson Correlation & $.482^{* *}$ & 1 & $.476^{* *}$ \\
& Sig. (2-tailed) & .000 & & .000 \\
Cost effectiveness & $\mathrm{N}$ & 146 & 146 & 146 \\
& Pearson Correlation & $.978^{* *}$ & $.476^{* *}$ & 1 \\
& Sig. (2-tailed) & .000 & .000 & 146 \\
\hline
\end{tabular}

**. Correlation is significant at the 0.01 level (2-tailed).

Source: Primary Data, 2020

The findings in Table 4.4 proved that there is a relationship between Efficiency and Project time line $(\mathrm{r}=.482$ and $\mathrm{p}=.000)$, between Efficiency and Cost effectiveness ( $\mathrm{r}=.978$ and $\mathrm{p}=.000)$, between Project time lineand Cost effectiveness $(r=.476$ and $\mathrm{p}=.000)$,

Table 4.5: Correlation analysis between M\&E practices and performance of public project

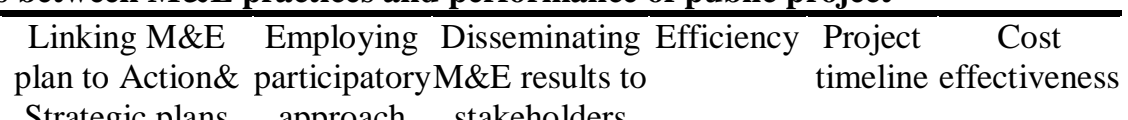

\begin{tabular}{|c|c|c|c|c|c|c|c|}
\hline \multirow{2}{*}{$\begin{array}{l}\text { Linking M\&E } \\
\text { plan to Action\& }\end{array}$} & P. Correlation & 1 & $.610^{* *}$ & $.970^{* *}$ & $.476^{* *}$ & $.987^{* *}$ & $.471^{* *}$ \\
\hline & Sig. (2-tailed) & & .000 & .000 & .000 & .000 & .000 \\
\hline Strategic plans & $\mathrm{N}$ & 146 & 146 & 146 & 146 & 146 & 146 \\
\hline \multirow{3}{*}{$\begin{array}{l}\text { Employing } \\
\text { participatory } \\
\text { approach }\end{array}$} & P. Correlation & $.610^{* *}$ & 1 & $.558^{* *}$ & $.496^{* *}$ & $.602^{* *}$ & $.469^{* *}$ \\
\hline & Sig. (2-tailed) & .000 & & .000 & .000 & .000 & .000 \\
\hline & $\mathrm{N}$ & 146 & 146 & 146 & 146 & 146 & 146 \\
\hline Disseminating & P. Correlation & $.970^{* *}$ & $.558^{* *}$ & 1 & $.455^{* *}$ & $.945^{* *}$ & $.472^{* * *}$ \\
\hline \multirow{3}{*}{$\begin{array}{c}\text { M\&E results to } \\
\text { stakeholders }\end{array}$} & Sig. (2-tailed) & .000 & .000 & & .000 & .000 & .000 \\
\hline & $\mathrm{N}$ & 146 & 146 & 146 & 146 & 146 & 146 \\
\hline & P. Correlation & $.476^{* *}$ & $.496^{* *}$ & $.455^{* *}$ & 1 & $.482^{* *}$ & $.978^{* *}$ \\
\hline \multirow[t]{2}{*}{ Efficiency } & Sig. (2-tailed) & .000 & .000 & .000 & & .000 & .000 \\
\hline & $\mathrm{N}$ & 146 & 146 & 146 & 146 & 146 & 146 \\
\hline \multirow{3}{*}{ Project timeline } & P Correlation & $.987^{* *}$ & $.602^{* *}$ & $.945^{* *}$ & $.482^{* *}$ & 1 & $.476^{* *}$ \\
\hline & Sig. (2-tailed) & .000 & .000 & .000 & .000 & & .000 \\
\hline & $\mathrm{N}$ & 146 & 146 & 146 & 146 & 146 & 146 \\
\hline \multirow{3}{*}{$\begin{array}{c}\text { Cost } \\
\text { effectiveness }\end{array}$} & P Correlation & $.471^{* *}$ & $.469^{* *}$ & $.472^{* *}$ & $.978^{* * *}$ & $.476^{* *}$ & 1 \\
\hline & Sig. (2-tailed) & .000 & .000 & .000 & .000 & .000 & \\
\hline & $\mathrm{N}$ & 146 & 146 & 146 & 146 & 146 & 146 \\
\hline
\end{tabular}

**. Correlation is significant at the 0.01 level (2-tailed).
Source: Primary Data, 2020

The findings in Table 4.5 proved that there is a Strategic plans and Efficiency $(r=.476$ and $p=.000)$, between Linking M\&E plan to Action\& Strategic between Linking M\&E plan to Action\& Strategic plans and Cost effectiveness $(r=.471$ and $p=.000)$ between Employing participatory approach and Efficiency $(r=.496$ and $\mathrm{p}=.000)$ between Employing participatory approach and Project time line $(r=.602$ and $\mathrm{p}=.000)$ between Employing participatory relationship between Linking M\&E plan to Action\& plans and Project time line $(\mathrm{r}=.987$ and $\mathrm{p}=.000)$, because all calculated $\mathrm{p}$ - values are less than 0.01 level of significance. Thus, implies that there is a positive relationship between Indicators of public project performance in Science and Technology Skills Development Project of MINEDUC. plan to Action\& participatoryM\&E results to

timeline effectiveness

approach and Cost effectiveness(r=.469 and $\mathrm{p}=.000)$ between Disseminating M\&E results to stakeholders and Efficiency $(\mathrm{r}=.455$ and $\mathrm{p}=.000)$ between Disseminating $\mathrm{M} \& \mathrm{E}$ results to stakeholders and Project time line $(r=.945$ and $\mathrm{p}=.000)$ between Disseminating M\&E results to stakeholders and Cost effectiveness $(r=.472$ and $p=.000)$ because all calculated p- values are less than 0.01 level of significance. Thus, implies that there is a positive relationship between predictors of M\&E practices and performance of Science and Technology Skills Development Project of MINEDUC, Rwanda. 
The study of Uitto (2010) supports the results of this study revealed that there is a relationship between predictors of M\&E practices and performance of Science and Technology Development Project because his study revealed that the link between M\&E plan, Strategic plan and work plan, employing participatory approach, dissemination of $\mathrm{M} \& \mathrm{E}$ results to stakeholders and use of data for project improvement have a positive correlation with effectiveness of $\mathrm{M} \& \mathrm{E}$ system with correlation coefficient of $0.754,0.736$ and 0.565 respectively.

Table 4.6: Model Summary of M\&E Practices and Efficiency

\begin{tabular}{ccccc}
\hline Model & R & R Square Adjusted R & $\begin{array}{c}\text { Std. Error of } \\
\text { Square }\end{array}$ & the Estimate \\
\hline 1 & $.543^{\mathrm{a}}$ & .294 & .279 & .92480 \\
\hline
\end{tabular}

a. Predictors: (Constant), Disseminating M\&E results to stakeholders, Employing participatory approach , Linking M\&E plan to Action\& Strategic plans

Source: Primary Data, 2020

The results in Table 4.6 indicated that that the $R$ coefficient .543 reveals that M\&E practices have a positive relationship with Efficiency. The coefficient of determination .294, R square also indicated thatM\&E practices explain $29.4 \%$ the progress variability in Efficiency. Thus, it implies that predictors of $M \& E$ practices such as Linking $M \& E$ plan to Action \& Strategic plans, employing participatory approach and Disseminating $\mathrm{M} \& \mathrm{E}$ results to stakeholders affect the progress of Efficiency by $29.4 \%$ in Science and Technology Skills Development Project.

Table 4.7: Analysis of Variance (ANOVA) of M\&E Practices and Efficiency

\begin{tabular}{cccccc}
\hline Model & $\begin{array}{c}\text { Sum of } \\
\text { Squares }\end{array}$ & Df & $\begin{array}{c}\text { Mean } \\
\text { Square }\end{array}$ & F & Sig. \\
\hline Regression & 50.663 & 3 & 16.888 & $19.745 .000^{\mathrm{b}}$ \\
Residual & 121.447 & 142 & .855 & \\
Total & 172.110 & 145 & & \\
\hline
\end{tabular}

a. Dependent Variable: Efficiency

b. Predictors: (Constant), Disseminating $\mathrm{M} \& \mathrm{E}$ results to stakeholders, Employing participatory approach, Linking M\&E plan to Action\& Strategic plans

Source: Primary Data, 2020

The findings in Table 4.7 indicated that there is significant relationship between M\&E practices and Efficiency because the calculated significance value .000 is less than 0.05 level of significance (calculated sig. value. $000<$ critical level of significance 0.05 ). Thus, the statistical model predicting the relationship between M\&E practices and Efficiency is significant.

Table 4.8: Coefficients of M\&E Practices and Efficiency

\begin{tabular}{lccccc}
\hline Model & \multicolumn{2}{c}{$\begin{array}{l}\text { Unstandardized } \\
\text { Coefficients }\end{array}$} & $\begin{array}{c}\text { Standardized } \\
\text { Coefficients }\end{array}$ & t & Sig. \\
\cline { 2 - 4 } & $\mathrm{B}$ & Std. Error & Beta & & \\
\hline (Constant) & .673 & .161 & & 4.174 & .000 \\
Linking M\&E plan to Action\& Strategic plans & .204 & .331 & .191 & .618 & .003 \\
Employing participatory approach & .371 & .101 & .333 & 3.680 & .000 \\
Disseminating M\&E results to stakeholders & .088 & .308 & .084 & .286 & .005 \\
\hline
\end{tabular}

a. Dependent Variable: Efficiency

Source: Primary Data, 2020

The results in Table 4.8 revealed that predictors of M\&E practices have positive coefficients that enhance positive effect on the progress of Efficiency in Science and Technology Skills Development project. The regression analysis indicated that there is a positive significant relationship between $\mathrm{M} \& \mathrm{E}$ practices and Efficiency because all the calculated pvalues are less than 0.05 each. Thus, the coefficient gives regression model, $Y=\beta_{0}+\beta_{1} X_{1}+\beta_{2} X_{2}+\beta_{3} X_{3}+\beta$. Therefore, the model becomes $\mathrm{Y}=.673+.204 \mathrm{x}_{1}+.371 \mathrm{x}_{2}+.088 \mathrm{x}_{3}$, this regression equation indicates that there is a positive significant between predictors of M\&E practices and Efficiency of Science and Technology Skills Development Project.
The first objective of establishing the relationship between linking M\&E plan to Action\& Strategic plans and Efficiency has a positive and significant relationship $(b=.204$ and $r=.003)$. The second objective of establishing the relationship between Disseminating M\&E results to stakeholders and Efficiency has a positive and significant relationship $(\mathrm{b}=.371$ and $\mathrm{p}=.000)$, the third objective of establishing the relationship between Employing participatory approach and Efficiency has a positive relationship $(\mathrm{b}=.088$ and $\mathrm{p}=.005)$. Thus, implies that there is a positive significant relationship between M\&E practices and Efficiency in Science and Technology Skills Development Project in Rwanda. The findings in Table 4.8 have revealed that there is a positive relationship between $M \& E$ practices and 
efficiency in Science and Technology skills Project in Rwanda. This means that M\&E practices have a positive effect on Science and Technology Skills Project efficiency which is also supported by the study of Crawford and Bryce (2013) conducted on project monitoring and evaluation with an emphasis on the methods that enhance effectiveness and efficiency in the aid project implementation. Their findings revealed that project monitoring and evaluation methods affect effective project implementation at $86.1 \%$ while efficiency is at $85.9 \%$ during implementation stage.

Table 4.9: Model Summary of M\&E Practices and project timeline

\begin{tabular}{ccccc}
\hline Model & $\mathrm{R}$ & $\begin{array}{c}\mathrm{R} \\
\text { Square }\end{array}$ & $\begin{array}{c}\text { Adjusted R } \\
\text { Square }\end{array}$ & $\begin{array}{c}\text { Std. Error of } \\
\text { the Estimate }\end{array}$ \\
\hline 1 & $.988^{\mathrm{a}}$ & .977 & .976 & .15826 \\
\hline
\end{tabular}

a. Predictors: (Constant), Disseminating M\&E results to stakeholders, Employing participatory approach , Linking M\&E plan to Action\& Strategic plans

Source: Primary Data, 2020

The results in Table 4.9 indicatedthat that the $R$ coefficient .988 reveals that $M \& E$ practices have a positive relationship with project timeline. The coefficient of determination $.977 \mathrm{R}$ square also indicates thatM\&E practices explains $97.7 \%$ the progress variability in project timeline. Thus, it implies that predictors of $M \& E$ practices such as
Linking M\&E plan to Action\& Strategic plans, Employing participatory approach and Disseminating M\&E results to stakeholders affect the progress of project timeline by $97.7 \%$ in Science and Technology Skills Development Project.

Table 4.2: Analysis of Variance (ANOVA) of M\&E Practices and project timeline

\begin{tabular}{cccccc}
\hline Model & $\begin{array}{c}\text { Sum of } \\
\text { Squares }\end{array}$ & Df & $\begin{array}{c}\text { Mean } \\
\text { Square }\end{array}$ & F & Sig. \\
\hline Regression & 150.662 & 3 & 50.221 & 2005.022 & $.000^{\mathrm{b}}$ \\
Residual & 3.557 & 142 & .025 & & \\
Total & 154.219 & 145 & & & \\
\hline
\end{tabular}

a. Dependent Variable: Project time line

b. Predictors: (Constant), Disseminating $\mathrm{M} \& \mathrm{E}$ results to stakeholders, Employing participatory approach , Linking M\&E plan to Action\& Strategic plans

\section{Source: Primary Data, 2020}

The findings in Table 4.10indicated that there is significant relationship between M\&E practices and project timeline because the calculated significance value .000 is less than 0.05 level of significance (calculated sig. value. $000<$ critical level of significance 0.05). Thus, the statistical model predicting the relationship between $\mathrm{M} \& \mathrm{E}$ practices and project timeline is significant.

Table 4.11: Coefficients of M\&E Practices and project timeline

\begin{tabular}{|c|c|c|c|c|c|}
\hline \multirow[t]{2}{*}{ Model } & \multicolumn{2}{|c|}{$\begin{array}{l}\text { Unstandardized } \\
\text { Coefficients }\end{array}$} & \multirow{2}{*}{$\begin{array}{c}\begin{array}{c}\text { Standardized } \\
\text { Coefficients }\end{array} \\
\text { Beta }\end{array}$} & \multirow[t]{2}{*}{$\mathrm{T}$} & \multirow[t]{2}{*}{ Sig. } \\
\hline & $\mathrm{B}$ & Std. Error & & & \\
\hline (Constant) & .024 & .028 & & .874 & .384 \\
\hline Linking M\&E plan to Action\& Strategic plans & 1.228 & .057 & 1.212 & 21.694 & .000 \\
\hline Employing participatory approach & -.013 & .017 & -.012 & -.739 & .001 \\
\hline Disseminating M\&E results to stakeholders & -.222 & .053 & -.224 & -4.207 & .000 \\
\hline
\end{tabular}

a. Dependent Variable: Project time line

Source: Primary Data, 2020

The results in table 4.11 revealed that predictors of M\&E practices have positive coefficients that enhance positive effect on the progress of project timeline in Science and Technology Skills Development Project. The regression analysis indicates that there is a positive significant relationship between $\mathrm{M} \& \mathrm{E}$ practices and project timeline because all the calculated p-values are less than 0.05 each. Thus, the coefficient gives regression model, $Y=\beta_{0}+\beta_{1} x_{1}+\beta_{2} x_{2}+\beta_{3} x_{3}+\beta$. Therefore, the model becomes $\mathrm{Y}=.024+.1 .228 \mathrm{x}_{1}+.013 \mathrm{x}_{2}+.222 \mathrm{x}_{3}$, this regression equation indicates that there is a positive significant relationship between predictors of M\&E practices and project timeline $s$ of Science and Technology Skills Development Project.
The first objective of establishing the relationship between Linking M\&E plan to Action\& Strategic plans and project timeline has a positive and significant relationship $(\mathrm{b}=.1 .228$ and $\mathrm{p}=.000)$. The second objective of establishing the relationship between Disseminating M\&E results to stakeholders and project timeline has a positive and significant relationship $(\mathrm{b}=.013$ and $\mathrm{p}=.001)$, the third objective of establishing the relationship between Employing participatory approach and project timeline has a positive relationship $(b=.222$ and $p=.000)$. Thus, implies that there is a positive significant relationship between M\&E practices and project timeline in Science and Technology Skills Development Project 
Table 4. 3: Model Summary of M\&E Practices and cost effectiveness

\begin{tabular}{lcccc}
\hline Model & $\mathrm{R}$ & $\begin{array}{c}\mathrm{R} \\
\text { Square }\end{array}$ & $\begin{array}{c}\text { Adjusted R } \\
\text { Square }\end{array}$ & $\begin{array}{c}\text { Std. Error of } \\
\text { the Estimate }\end{array}$ \\
\hline 1 & $.534^{\mathrm{a}}$ & .286 & .270 & .95712 \\
\hline a. Predictors: (Constant), Disseminating M\&E results \\
to stakeholders , Employing participatory approach , \\
Linking M\&E plan to Action\& Strategic plans \\
Source: Primary Data, 2020
\end{tabular}

The results in Table 4.12 indicated that the $R$ coefficient .534 reveals that M\&E practices has a positive relationship with cost effectiveness. The coefficient of determination .286, R square also indicated thatM\&E practices explain $28.6 \%$ the progress variability in cost effectiveness. Thus, it implies that predictors of $M \& E$ practices such as Linking M\&E plan to Action \& Strategic plans, Employing participatory approach and Disseminating M\&E results to stakeholders affect the progress of cost effectivenessby $28.6 \%$ in Science and Technology Skills Development Project.
Table 4. 4: Analysis of Variance (ANOVA) of M\&E Practices and cost effectiveness

\begin{tabular}{ccclll}
\hline Model & $\begin{array}{c}\text { Sum of } \\
\text { Squares }\end{array}$ & Df & $\begin{array}{l}\text { Mean } \\
\text { Square }\end{array}$ & F & Sig. \\
\hline Regression & 51.998 & 3 & 17.333 & 18.920 & $.000^{\mathrm{b}}$ \\
Residual & 130.084 & 142 & .916 & & \\
Total & 182.082 & 145 & & & \\
\hline
\end{tabular}

a. Dependent Variable: Cost effectiveness

b. Predictors: (Constant), Disseminating M\&E results to stakeholders, Employing participatory approach, Linking M\&E plan to Action\& Strategic plans

Source: Primary Data, 2020

The findings in Table 4.13 indicated that there is significant relationship between $\mathrm{M} \& \mathrm{E}$ practices and cost effectivenessbecause the calculated significance value .000 is less than 0.05 level of significance (calculated sig. value.000< critical level of significance 0.05). Thus, the statistical model predicting the relationship between $\mathrm{M} \& \mathrm{E}$ practices and project timeline is significant.

Table 4. 5: Coefficients of M\&E Practices and cost effectiveness

\begin{tabular}{lccccc}
\hline Model & \multicolumn{2}{c}{$\begin{array}{c}\text { Unstandardized } \\
\text { Coefficients }\end{array}$} & $\begin{array}{c}\text { Standardized } \\
\text { Coefficients }\end{array}$ & T & Sig. \\
\cline { 2 - 5 } & B & Std. Error & Beta & & \\
\hline (Constant) & .662 & .167 & & 3.966 & .000 \\
Linking M\&E plan to Action\& Strategic plans & -.173 & .342 & -.157 & -.506 & .003 \\
Employing participatory approach & .360 & .104 & .314 & 3.449 & .001 \\
Disseminating M\&E results to stakeholders & .483 & .319 & .450 & 1.515 & .002 \\
\hline
\end{tabular}

a. Dependent Variable: Cost effectiveness

Source: Primary Data, 2020

The results in Table 4.14 revealed that predictors of M\&E practices have positive coefficients that enhance positive effect on the progress of cost effectivenessin Science and Technology Skills Development Project. The regression analysis indicated that there is a positive significant relationship between $\mathrm{M} \& \mathrm{E}$ practices and cost effectivenessbecause all the calculated p-values are less than 0.05 each. Thus, the coefficient gives regression model, $\quad \mathrm{Y}=\beta_{0}+\beta_{1} \mathrm{x}_{1}+\beta_{2} \mathrm{x}_{2}+\beta_{3} \mathrm{x}_{3}+\beta$. Therefore, the model becomes $\mathrm{Y}=.662+.173 \mathrm{x}_{1}+.360 \mathrm{x}_{2}+.483 \mathrm{x}_{3}$, this regression equation indicates that there is a positive significant between predictors of $\mathrm{M} \& \mathrm{E}$ practices and cost effectiveness of Science and Technology Skills Development Project.

The first objective of establishing the relationship between Linking M\&E plan to Action\& Strategic plans and cost effectivenesshas a positive and significant relationship $(b=.173$ and $p=.003)$. The second objective of establishing the relationship between Disseminating M\&E results to stakeholders andcost effectivenesshas a positive and significant relationship $(b=.360$ and $p=.001)$, the third objective of establishing the relationship between Employing participatory approach and cost effectivenesshas a positive relationship $(\mathrm{b}=.483$ and $\mathrm{p}=.002)$. Thus, implies that there is a positive significant relationship between M\&E practices and cost effectivenessin Science and Technology Skills Development Project.

\section{Conclusion}

The findings proved that there is a relationship between M\&E practices and performance of public projects for instance there is relationship between Linking M\&E plan to Action\& Strategic plans and Efficiency ( $\mathrm{r}=.476$ and $\mathrm{p}=.000)$, between Linking M\&E plan to Action\& Strategic plans and Project time line $(r=.987$ and $p=.000)$, between Linking M\&E plan to Action\& Strategic plans and Cost effectiveness $(r=.471$ and $p=.000)$ between Employing participatory approach and Efficiency $(\mathrm{r}=.496$ and $\mathrm{p}=.000)$ between Employing participatory approach and Project time line $(r=.602$ and $\mathrm{p}=.000$ ) between Employing participatory 
approach and Cost effectiveness( $\mathrm{r}=.469$ and $\mathrm{p}=.000)$ between Disseminating M\&E results to stakeholders and Efficiency $(\mathrm{r}=.455$ and $\mathrm{p}=.000)$ between Disseminating M\&E results to stakeholders and Project time line $(r=.945$ and $\mathrm{p}=.000)$ between Disseminating M\&E results to stakeholders and Cost effectiveness ( $r=.472$ and $\mathrm{p}=.000)$ because all calculated $\mathrm{p}$ - values are less than 0.01 level of significance. Thus, implies that there is a relationship between predictors of $\mathrm{M} \& \mathrm{E}$ practices and performance of Science and Technology Skills Development Project of MINEDUC, Rwanda.

The results reveal that predictors of $M \& E$ practices have positive coefficients that enhance positive effect on the progress of Efficiency in Science and Technology Skills Development Project. The regression analysis indicates that there is a positive significant relationship between M\&E practices and Efficiency because all the calculated p-values are less than 0.05 each. Thus, the coefficient gives regression model, $\quad \mathrm{Y}=\beta_{0}+\beta_{1} \mathrm{x}_{1}+\beta_{2} \mathrm{x}_{2}+\beta_{3} \mathrm{x}_{3}+\beta$. Therefore, the model becomes $\mathrm{Y}=.673+.204 \mathrm{x}_{1}+.371 \mathrm{x}_{2}+.088 \mathrm{x}_{3}$, this regression equation indicates that there is a positive significant between predictors of M\&E practices and Efficiency of Science and Technology Skills Development Project.

\section{Acknowledgement}

I thank God for practice and safety as I write my search idea. I can never forget the contribution of my research supervisor Dr. James Kant Kamuhanda while corrections and other directions given to me during this study. I owe a big appreciation the Ministry of Education leadership who facilitated collection of data on Science and Technology Skills Development Project.

I also owe many thanks to my colleagues at MKU, my lecturers and other staff of MKU who made my studies more joyful with provision of all required facilitation to complete.

\section{REFERENCE}

1. Buttrick, R. (2007). The project workout: a toolkit for reaping the rewards from your entire business project. Financial times management. 25 (4), 11-13.

2. Bryde, D. (2008) Perceptions of the impact of project sponsorship practices. International Journal of Project Management 26(8):800-809.
ISSN 2455-6378

3. Cheung, S. O., Henry, C. \& Kevin K. (2014). PPMS: a Web-based construction Project Performance Monitoring System. International Journal of Construction, 13, 361-376.

4. Crawford, P. \& Bryce, P. (2013). Project Monitoring and Evaluation: A method of enhancing the efficiency and effectiveness of aid project implementation. International Journal of Project Management, 21(5): 363 - 37319.

5. Doolen (2003). The impact of organizational context on work team effectiveness: A study of production team.

6. Kimweli, J.M (2013). The role of Monitoring and Evaluation Practices to the Success of Donor funded Food Security Intervention Projects. A case study of Kibwezi District, Kenya: Nairobi

7. Kusek, J.Z \&Rist, R. (2010). A hand book for development practitioner. The step to results based monitoring and evaluation systems; Washington. D.C. World Bank.

8. Muller \& Turner, (2007). Matching the project manager's leadership style to project type. International journal of Project management 25 (2007)21-32.

9. Pinto \&Slevin (2008). Success criteria and factors for international development projects. A life-Cycle-Based Framework, New York: Van Nostrand.

10. Pinto \&Mantel, (2009). Generic Project success and Project management criteria and factors, Australia: Adelaide

11. Porter, S. \& Goldman, I. (2013). A growing demand for Monitoring and Evaluation in Africa. African Evaluation journal. 1 (1) 1-9

12. Shenhar, A. J. (2011). An empirical analysis of the relationship between project planning and project success. International Journal of Project Management, 21(20), 89-95.

13. Uitto, J. A. (2010). Multi-country co-operation around shared waters: Role of Monitoring and Evaluation. International Journal of Global Environmental Change, 14(1): $5-14$

14. USAID, (2019).Best practices in Monitoring and Evaluation: Lessons from the USAID Turkey Population Program. Turkey: Ankara.

15. World Bank, (2010a).Handbook on planning, monitoring and evaluation for development results. New York. USA.

16. World Bank, (2010b):Handbook of Monitoring and Evaluation for Results. New York: USA 